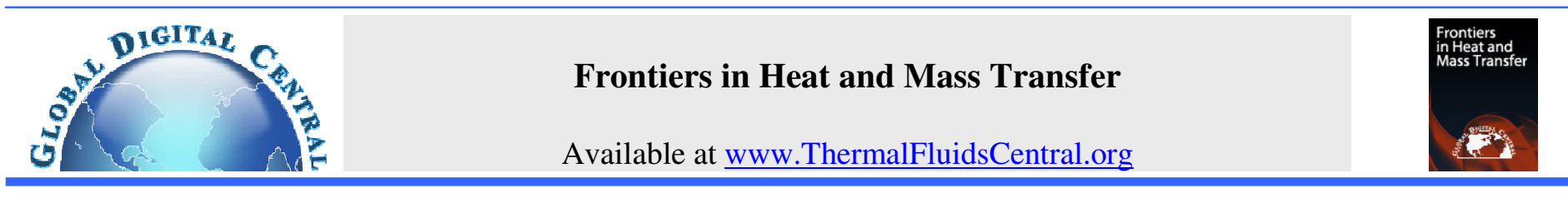

\title{
OPTIMIZATION OF COMPRESSION RATIO OF JATROPHA OIL BLEND WITH DIESEL FUELLED ON VARIABLE COMPRESSION RATIO ENGINE
}

\author{
Biswajit De*, Rajsekhar Panua \\ Mechanical Engineering Department, National Institute of Technology, Agartala, Tripura, 799055, India
}

\begin{abstract}
As the world is facing crisis due to the dwindling resources of fossil fuels, rapid depletion of conventional energy is a matter of serious concern for the mankind. So there is a necessity to find alternate fuels. Vegetable oils, because of their agricultural origin, due to less carbon content compared to mineral diesel are producing less $\mathrm{CO}_{2}$ emissions to the atmosphere is used as an alternate fuel in substitute to diesel fuel. In the present study optimum compression ratio for VCR diesel engine fuelled with Jatropha oil blends with diesel (30\%) has been determined at 203 bars injector opening pressure, $23^{\circ} \mathrm{CA}$ BTDC injection timing and at $1500 \mathrm{rev} / \mathrm{min}$ rated speed. The test results revealed that compression ratio 19 exhibited better performance and lower emissions and hence, is considered as optimum compression ratio.

Keywords: Variable compression ratio engine; optimum; blend; emissions;
\end{abstract}

\section{INTRODUCTION}

Energy is the most important component of human life and is an essential input for every activity. With ever growing population, improvement in the living standard of humanity, industrialization of developing countries, the global demand for energy is expected to rise rather significantly in the near future. The rapid depletion of petroleum reserves and rising oil prices has led to the search for alternative fuels. Non edible oils are promising fuels for power requirement of agricultural applications. Thomas and Maurin (1993) explained that vegetable oil is renewable, environmental- friendly and produced easily in rural areas, where there is an acute need for modern forms of energy. Therefore in recent years systematic efforts have been made by several research workers to use vegetable oils as fuel in engines. From previous studies, it is evident that there are various problems associated with vegetable oils being used as fuel in compression ignition engines, mainly caused by their high viscosity. Agarwal reported that due to the high viscosity, in long term operation, vegetable oils normally (2007) introduce the development of gumming, the formation of injector deposits, ring sticking, as well as incompatibility with conventional lubricating oils. Therefore, a reduction in viscosity is of prime importance to make vegetable oils a suitable alternative fuel for diesel engines. Rakopoulos et al. (2006) performed tests to evaluate and compare the use of a variety of vegetable oil of various origin as a substitute to conventional diesel fuel at blend ratios of 10/90 and 20/80 in a DI (direct injection) diesel engine. The obtained data was analyzed for various parameters such as thermal efficiency, BSFC (brake specific fuel consumption), smoke opacity, and $\mathrm{CO} 2, \mathrm{CO}$ and $\mathrm{HC}$ emissions. It was found that NOx emissions were reduced with use of vegetable oil in the diesel engine. Altuna and Bulut (2008) reported that their experimental results show that the engine power and torque of the mixture of sesame oil-diesel fuel are close to the values obtained from diesel fuel and the amounts of exhaust emissions are lower than those of diesel fuel. Hence, it is seen that blend of sesame oil and diesel fuel can be used as an alternative fuel successfully in a diesel engine without any modification and also it is an environmental friendly fuel in terms of emission parameters. Chen and Wang (2008) stated that hydrocarbon is apparently decreased when the engine was fueled with ethanol-esterdiesel blends. Hydrocarbon Fuelling the engine with oxygenated diesel fuels showed increased carbon monoxide (CO) emissions at low and medium loads, but reduced $\mathrm{CO}$ emissions at high and full loads, when compared to pure diesel fuel. Jindal and Nandwana (2010) found that the combined increase of compression ratio and injection pressure increases the BTHE and reduces BSFC while having lower emissions. For small sized direct injection constant speed engines used for agricultural applications $(3.7 \mathrm{~kW})$, the optimum combination was found as CR of 19 with IP of 250 bar. Pradhan and Raheman (2014) reduced the viscosity and density of CJO (crude Jatropha oil) by heating it using the heat from exhaust gas of a diesel engine with an appropriately designed helical coil heat exchanger. Experiments were conducted to evaluate the combustion characteristics of a DI (direct injection) diesel engine using PJO (preheated Jatropha oil). The results indicated that BSFC (brake specific fuel consumption) and EGT (exhaust gas temperature) increased while BTE (brake thermal efficiency) decreased with PJO as compared to HSD (high speed diesel) for all engine loadings. The reductions in $\mathrm{CO}_{2}$ (carbon dioxide), $\mathrm{HC}$ (hydrocarbon) and NOx (nitrous oxide) emissions were observed for PJO along with increased $\mathrm{CO}$ (carbon monoxide) emission as compared to those of HSD. Pilusa and Mollaggee (2012) used Vehicle Emissions Analyser to measure the emissions at each stage, and a similar procedure was followed to measure the emissions after installation of the Whale filter. The results showed a significant average reduction in carbon monoxide CO (35.3\%), nitrogen oxides NOx (26.1\%) and hydrocarbons HC (34.3\%) emissions after the Whale filter was installed in the four vehicles.

\footnotetext{
* Corresponding author. Email: biswajitde62@gmail.com
} 


\section{EXPERIMENTAL SETUP}

A single cylinder, direct injection, four-stroke, vertical, watercooled, naturally aspirated variable compression ratio diesel engine with a bore of $80 \mathrm{~mm}$ and a stroke of $110 \mathrm{~mm}$ is selected for the present study. Labview based Engine Performance Analysis software package "EnginesoftLV" is provided for on line performance evaluation. The engine is connected to eddy current type dynamometer for loading. The compression ratio can be changed without stopping the engine and without altering the combustion chamber geometry by specially designed tilting cylinder block arrangement. The technical specification of the test engine is given in Table 1 and the different properties of Diesel and Jatropha oil are given in Table 2. The schematic diagram of the experiment set up is shown in Fig. 1.The set up has stand-alone panel box consisting of air box, two fuel tanks for duel fuel test, manometer, fuel measuring unit, transmitters for air and fuel flow measurements, process indicator and engine indicator. 30\% Jatropha oil blend with diesel is prepared. One litre of 30\% Jatropha oil blend contains $700 \mathrm{ml}$ of diesel and $300 \mathrm{ml}$ of jatropha oil. For warm-up the engine, it is started with diesel and then switched over to blended oil.

Table 1 Specification of the test engine.

\begin{tabular}{|c|c|c|}
\hline S. No & Parameters & Specification \\
\hline 1. & $\begin{array}{l}\text { General } \\
\text { Details }\end{array}$ & $\begin{array}{l}\text { Single cylinder, four stroke } \\
\text { compression ignition engine, } \\
\text { constant speed, vertical, } \\
\text { water cooled, direct injection }\end{array}$ \\
\hline 2. & Stroke & $110 \mathrm{~mm}$ \\
\hline 3. & Bore & $87.5 \mathrm{~mm}$ \\
\hline 4. & Displacement & $661 \mathrm{cc}$ \\
\hline 5. & Compression ratio & 17.5 \\
\hline 6. & Rated output & $3.7 \mathrm{KW}$ \\
\hline 7. & Rated speed & $1500 \mathrm{rpm}$ \\
\hline
\end{tabular}

Table 2 Properties of mineral diesel and Jatropha oil.

\begin{tabular}{|l|c|c|}
\hline Property & Mineral diesel & Jatropha oil \\
\hline Density $\left(\mathrm{kg} / \mathrm{m}^{3}\right)$ & 841 & 917.5 \\
\hline API gravity & 37.123 & 22.8925 \\
\hline Kinematic viscosity at $40^{0} \mathrm{C}(\mathrm{cSt})$ & 2.575 & 36.63 \\
\hline Pour point $\left({ }^{0} \mathrm{C}\right)$ & -6 & 4.5 \\
\hline Fire point $\left({ }^{0} \mathrm{C}\right)$ & 104 & 275 \\
\hline Cloud point $\left({ }^{0} \mathrm{C}\right)$ & 3.5 & 9.5 \\
\hline Flash point $\left({ }^{0} \mathrm{C}\right)$ & 72 & 230 \\
\hline Calorific value $(\mathrm{MJ} / \mathrm{kg})$ & 44.864 & 38.6355 \\
\hline Carbon $(\%, \mathrm{w} / \mathrm{w})$ & 80.32 & 76.113 \\
\hline Hydrogen $(\%, \mathrm{w} / \mathrm{w})$ & 12.358 & 10.517 \\
\hline Nitrogen $(\%, w / w)$ & 1.758 & 0 \\
\hline
\end{tabular}

Fuel from valve enters into the engine through fuel measuring unit, which enables the volumetric flow of the fuel to be measured easily. Engine start at no load conditions at CR of 15 and varying the load from idle to rated load of $3.7 \mathrm{~kW}$ in a number of steps and a set of readings are obtained for fuel consumption, rpm, exhaust temperature,
$\mathrm{NO}_{\mathrm{X}}, \mathrm{CO}_{2}$, smoke opacity and power output. Similar set of readings are recorded for $\mathrm{CR}$ of $16,17,18$ and 19. The emissions $\left(\mathrm{NO}_{\mathrm{X}}, \mathrm{CO}_{2}\right.$, concentrations) are recorded by using Gas Analyzer (AVL Di Gas 444) and the opacity is recorded by smoke meter (AVL 437). The accuracy of the measured values is ensured by calibrating the gas analyzer using reference gases before each measurement and allowing the smoke meter to adjust its zero point before each measurement.For each setting, the emission values and the other values are recorded thrice and a mean of these is taken for comparison. The performance of the engine at different loads and settings are evaluated in terms of BSFC, brake thermal efficiency and emissions of carbon dioxide, oxides of nitrogen, smoke opacity and exhaust gas temperature.

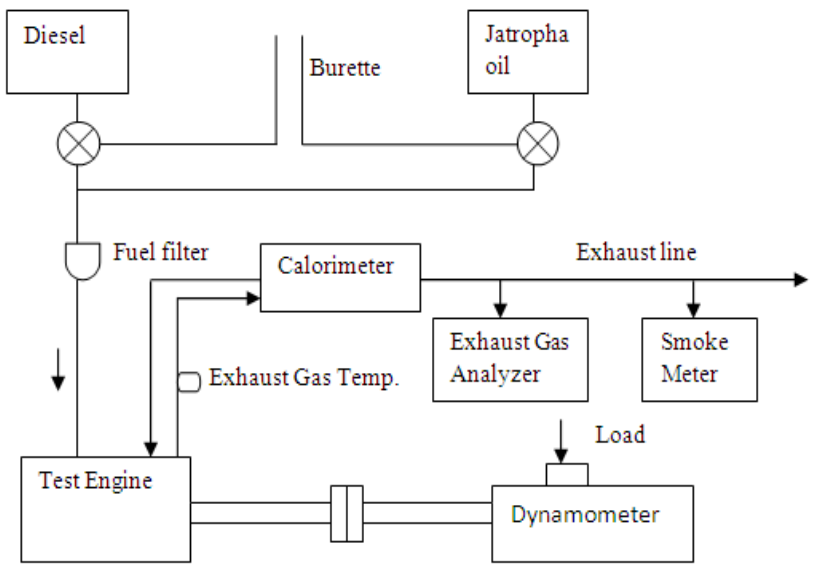

Fig. 1 Schematic diagram of experimental setup.

\section{RESULTS AND DISCUSSIONS}

In order to determine the optimum compression ratio for variable compression ratio diesel engine fuelled with Jatropha oil blend with diesel $(30 \%)$ and the engine is started at no load conditions at CR of 15 and varying the load from idle to rated load of $3.7 \mathrm{~kW}$ in a number of steps and a set of reading is obtained. Fuel consumption, rpm, exhaust temperature, $\mathrm{NO}_{\mathrm{X}}, \mathrm{CO}$ and power output are measured. Similar set of readings are recorded for $\mathrm{CR}$ of $15,16,17,18$ and 19 by changing it using the tilting cylinder head arrangement. For all settings, the emission values and the other values are recorded thrice and a mean of these is taken for comparison for entire load conditions and compression ratios of $15,16,17,18$ and 19 while maintaining the injection pressure of 203 bars and $23^{\circ}$ CA BTDC injection timing at rated speed of $1500 \mathrm{rev} / \mathrm{min}$. The optimization is done on the basis of maximum brake thermal efficiency.

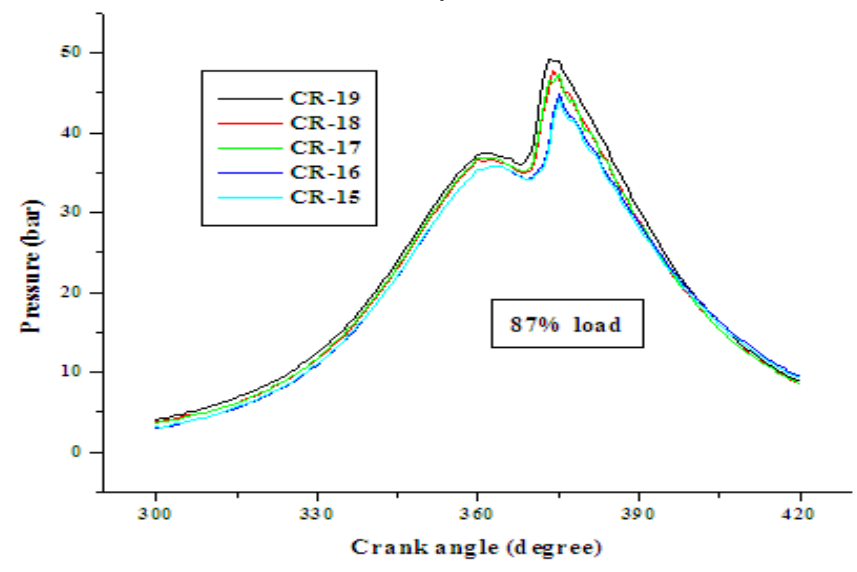

Fig. 2 Pressure rise diagram at different CR. 
Figure 2 shows that in-cylinder pressure increase with increase of engine load and compression ratio. At CR of 19, the pressure rise inside the engine cylinder is higher and lower at CR of 15.It happened due to the reason that at CR of 19 better combustion of air-fuel mixture takes place. Fig. 3 shows the variations of brake thermal efficiency with respect to load at different compression ratios for diesel fuel engine operation. The value of brake thermal efficiency of dual fuel engine is low at low loads but significantly high at higher engine loads because at low loads the fuel air ratio of the air-fuel mixture is very less, resulting in incomplete flame propagation and most of the fresh air-gas mixture remains unburnt.

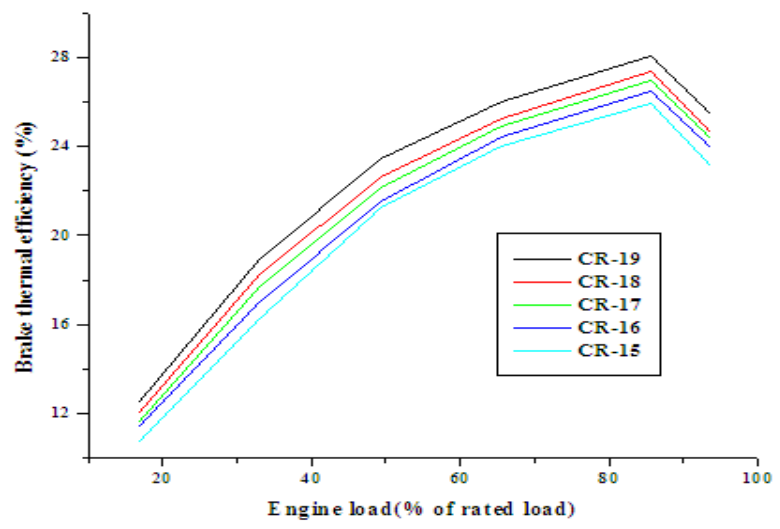

Fig. 3 Variation of brake thermal efficiency with respect to load at different $\mathrm{CR}$.

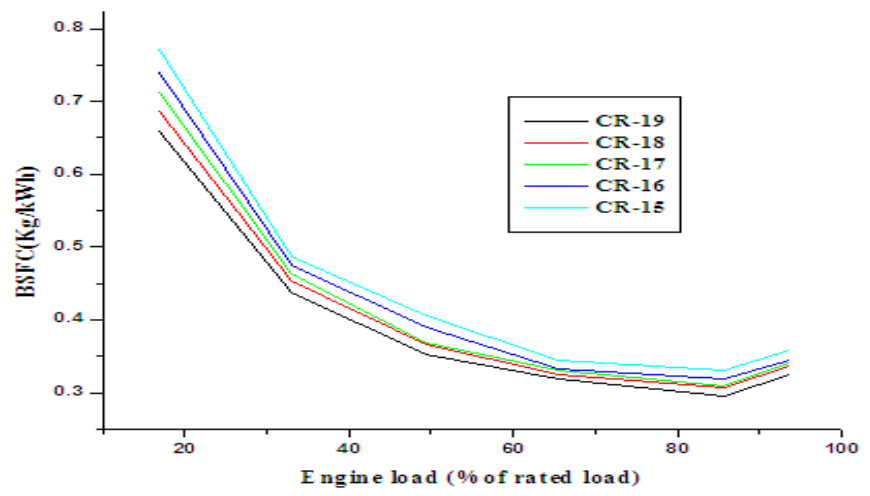

Fig. 4 BSFC with load at different CR.

At higher engine loads, fuel-air ratio increases, resulting in complete combustion and increase in brake thermal efficiency. The maximum brake thermal efficiency is obtained at a CR of 19, due to the superior combustion and better intermixing of the fuel. The brake thermal efficiency at CR of 18 is also very close to that of maximum brake thermal efficiency, particularly at higher loads. The least brake thermal efficiency is obtained at a CR of 15 . The CR of 19, is found to be the best for all load conditions. The change of compression ratio from 15 to 19 resulted in, $2.81 \%, 3.8 \%, 4.01 \%$, and $5.14 \%$ increase in brake thermal efficiency at $65 \%$ load and $2.61 \%, 3.12 \%, 4.87 \%$, and $5.48 \%$ at $87 \%$ load respectively. This improved performance of the engine at higher compression ratio may be due to higher temperatures resulted in the combustion chamber which reduces the volatility and ignition delay of the blended fuel and the maximum thermal efficiency can be attributed to the superior combustion and better intermixing of air and fuel at optimum compression ratio. Rakopoulos et al obtains the same results. The comparison of brake specific fuel consumption with varying load is presented in Fig. 4 at $1500 \mathrm{rev} / \mathrm{min}$. The least fuel consumption is obtained at compression ratio of 19 . The fuel consumption at $\mathrm{CR}=18$ is found very close to optimum value. At the lower sides of the compression ratios, the fuel consumption is higher due to higher viscosity and poor volatility of the blended fuel.

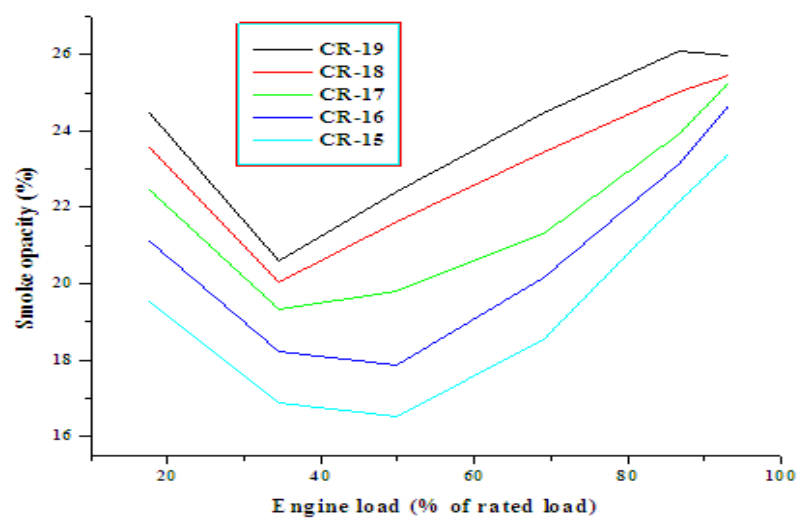

Fig. 5 Variation of Smoke opacity with respect to load at different CR.

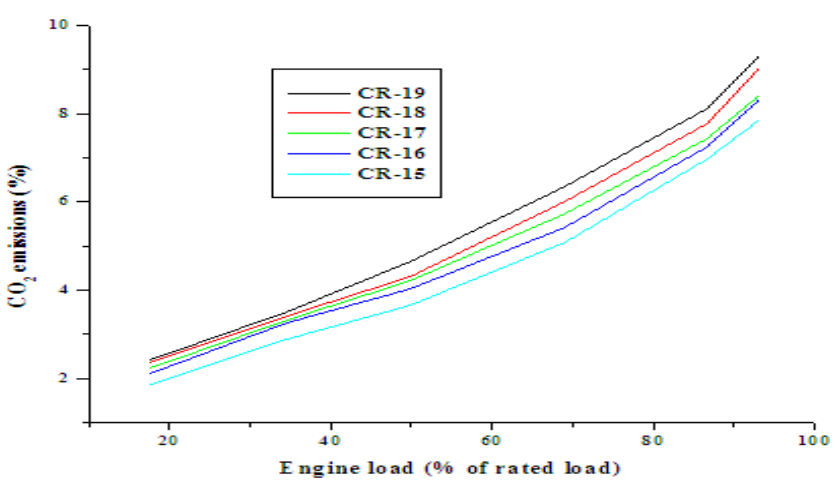

Fig. 6 Comparison of $\mathrm{CO}_{2}$ emissions with load at different $\mathrm{CR}$.

The variation of smoke opacity with varying engine load is presented in Fig. 5. Smoke opacity increases with the increase in load. This may be due proper mixing at fuel rich region and rising of combustion temperature. Smoke opacity at CR of 19 is found highest and this is because of better combustion at optimum compression ratio. Altuna and Bulut obtained the same results.

Figure 6 presents the variation of carbon dioxide emission with load at different compression ratios. It is observed that the carbon dioxide emission at compression ratio of 19 is higher. This is due to superior combustion which takes place at optimum compression ratio. More amount of $\mathrm{CO}_{2}$ is an indication of complete combustion of carbon molecule present in fuel. However, more amount of $\mathrm{CO}_{2}$ is not much harmful to human beings but is leading to higher ozone depletion potential and global warming.

NOx emission with varying engine load is shown in Fig.7. NOx emission increases with increase in load at all the compression ratios. At low load, rich air-fuel mixture causes incomplete combustion, but at higher load conditions proper mixing at fuel rich region results in complete combustion and rising of combustion temperature. NOx emission at compression ratio of 19 is found highest and this is because of better combustion at optimum compression ratio. $\mathrm{NO}_{\mathrm{X}}$ emissions at compression ratio of 19 are found about $445.3 \mathrm{ppm}$ which is equivalent to $2.83(\mathrm{~g} / \mathrm{kWh})$ according to the Eq. (1) (Pilusa et al., 2012) and this value is within the permissible range of $\mathrm{NO}_{\mathrm{X}}$ emissions with respect to Bharat stage emission standards are emission standards instituted by 
the Government of India to regulate the output of air pollutants from internal combustion engine equipment, including motor vehicles. The standards and the timeline for implementation are set by the Central Pollution Control Board under the Ministry of Environment \& Forests (http://cpcb.nic.in/Functions.php).

$$
E P_{i, w}(g / k W h)=\frac{E V_{i, w}(p p m)}{1 \times 10^{6}} \times\left(\frac{M_{i}}{28.84 g / m o l} \times 4160 g / k W h\right)
$$

where $E P i, w$ is pollutant mass, i, referenced to Peff $(\mathrm{g} / \mathrm{kWh}), E V i, w$ is exhaust emission value of components on wet basis, $i$ is volume share (ppm), and $M i$ is molecular mass of the components, $\mathrm{i},(\mathrm{g} / \mathrm{mol})$.

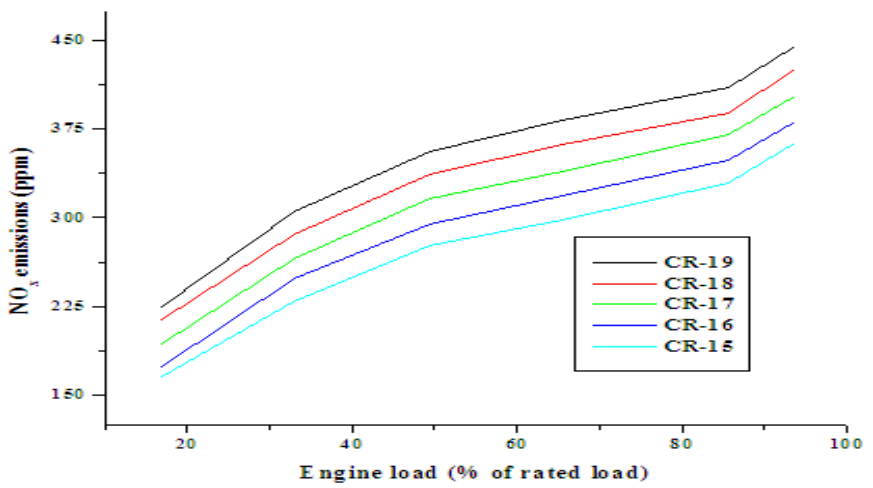

Fig. 7 Variation of $\mathrm{NO}_{\mathrm{X}}$ emissions with load at CR.

\section{CONCLUSIONS}

The following are the main conclusions drawn after extensive tests results on Jatropha-diesel blend (30\%) operation on variable compression ratio diesel engine.

- At rated speed of $1500 \mathrm{rev} / \mathrm{min}$, the compression ratio 19 shows highest brake thermal efficiency, and hence, may be considered as optimum compression ratio for variable compression ratio diesel engine. CR of 18 exhibited marginally lower brake thermal efficiency compared to optimum compression ratio.

- Better fuel economy is observed at CR of 19 compared to other compression ratios.

- Highest smoke opacity, carbon dioxide and NOx emissions are observed at compression ratio of 19 for blending fuel operation. Hence, the test results show that the compression ratio 19 seems to be over all optimum compression ratio for blending fuel operation.

\section{NOMENCLATURE}

VCR Variable compression ratio

$C A \quad$ Crank angle

BTDC Before Top Dead Centre
$B S F C \quad$ Brake specific fuel consumption

$C R \quad$ Compression ratio

$\mathrm{CO}_{2} \quad$ Carbon dioxide

$N O_{x} \quad$ Oxides of Nitrogen

J30 $\quad 30 \%$ Jatropha oil and $70 \%$ Diesel oil in blends

\section{REFERENCES}

Agarwal, A. K., 2007, "Biofuels (Alcohols and Biodiesel): Applications as Fuels for Internal Combustion Engines," Progress in Energy and Combustion Science, 33, 233-271. http://dx.doi:10.1016/j.pccs.2006.08.003

Altuna, S., Bulut, H. and Oner, C., 2008 "The Comparison of Engine Performance and Exhaust Emission Characteristics of Sesame OilDiesel Fuel Mixture with Diesel Fuel in a Direct Injection Diesel Engine," Renewable Energy, 33, 1791-1799. http://dx.doi:10.1016/j.renene.2007.11.008

Chen, H., Wang, J. and Shuai, S., 2008 "Study of Oxygenated Biomass Fuel Blends on a Diesel Engine," Fuel, 87, 3462-3468. http://dx.doi:10.1016/j.fuel.2008.04.034

Jindal, S., Nandwana, B. P. and Rathore, N. S., 2010 "Experimental Investigation of the Effect of Compression Ratio and Injection Pressure in a Direct Injection Diesel Engine Running on Jatropha Methyl Ester," Applied Thermal Engineering, 30, 442-448. http://dx.doi:10.1016/j.applthermaleng.2009.10.004

Pilusa, T. J. and Mollaggee, M. M., 2012, "Reduction of Vehicle Exhaust Emissions from Diesel Engines Using the Whale Concept Filter," Aerosol and Air Quality Research, 12, 994-1006. http://dx.doi:10.4209/aaqr.2012.04.0100

Pradhan, P. and Raheman, H., 2014, "Combustion and Performance of a Diesel Engine with Preheated Jatropha Curcas Oil Using Waste Heat from Exhaust Gas," Fuel,115, 527-533.

http://dx.doi.org/10.1016/j.fuel.2013.07.067

Rakopoulos, C. D, Antonopoulos, K. A., Rakopoulos, D. C., Hountalas, D. T., Giakoumis, E. G., 2006 "Comparative Performance and Emissions Study of a Direct Injection Diesel Engine Using Blends of Diesel Fuel with Vegetable Oils or Biodiesels of Various Origins," Energy Conversion and Management, 47, 3272-3287. http://dx.doi:10.1016/j.enconman.2006.01.006

Rakopoulos, C. D, Antonopoulos, K. A., Rakopoulos, D. C., Hountalas, D. T., Giakoumis, E. G., 2006 "Development and Application of MultiZone Model for Combustion and Pollutants Formation in Direct Injection Diesel Engine Running with Vegetable Oil or Its Bio-Diesel," Energy Conversion and Management, 48, 1881-1901. http://dx.doi:10.1016/j.enconman.2007.01.026

Thomas, R. W. and Maurin, B. O., 1993, "Identification of Chemical Change Occurring during the Transient Injection of Selected Vegetable Oils," SAE Technical Paper Series, 930933. 